University of Massachusetts Amherst

From the SelectedWorks of Benjamin Bailey

2017

Greetings and compliments or street harassment: Competing evaluations of street remarks in a recorded collection

Benjamin Bailey 


\title{
Greetings and compliments or street harassment? Competing evaluations of street remarks in a recorded collection
}

\section{Benjamin Bailey}

University of Massachusetts Amherst, USA

\begin{abstract}
In this article I evaluate competing discourses about the meaning of street remarks - the remarks men make to unacquainted women passing on the street - in 1000 comments posted to a YouTube video of street remarks recorded in New York City in 2014. One discourse prominent in the comments posted to the video defends the remarks as civil talk, highlighting the literal meanings of remarks such as 'Have a nice evening'. A second, less frequent, discourse characterizes these encounters and utterances as sexual harassment, citing men's ostensible sexual intentions and personal experience. I find that (a) difficulties in articulating the ways in which street remarks are injurious may veil their harm, thus contributing to the perpetuation of male domination of women in public spaces, and (b) the close juxtaposition of explicitly misogynistic comments with interpretations of the street remarks as civil casts doubt on the sincerity of such interpretations.
\end{abstract}

\section{Keywords}

'I 0 Hours of Walking in NYC as a Woman', catcalls, language and gender, male-female interaction, street harassment, street remarks

\section{Introduction}

In this article I explore two competing discourses about the meaning of street remarks - the remarks men make to unacquainted women passing on the street - based on comments posted to a viral YouTube video. The video ' 10 Hours of Walking in NYC as a

\footnotetext{
Corresponding author:

Benjamin Bailey, Department of Communication, Integrative Learning Center, University of Massachusetts Amherst, Amherst, MA 0I003, USA.

Email: bbailey@umass.edu
} 
Woman' (https://www.youtube.com/watch?v=b1XGPvbWn0A) was published on YouTube on 28 October 2014. In the video, 23-year-old Shoshanna Roberts is shown walking through various neighborhoods of New York City carrying a microphone in each hand and recording remarks directed at her while she is video-recorded by Robert Bliss, who ran a small video-marketing agency. He had been commissioned by Hollaback!, a non-profit movement dedicated to combating street harassment, to record a video. The video he produced is a 1-minute 56-second compilation that documents 20 encounters with street remarks. The posted video went viral with over 1 million views in 24 hours. As of December 2016, it had been viewed over 43 million times and generated over 153,000 comments on YouTube.

I use the term 'street remarks', adopted from Gardner $(1980,1995)$, to refer to the things men say to Roberts in their public encounters. This term is general enough to encompass the range of things that men say in this video, from the relatively intrusive to the relatively civil (e.g. 'How you doing?'), and it marks continuity with Gardner's Goffman-inspired interactional and phenomenological tradition. It also avoids the legal conceptual frameworks associated with the terms 'street harassment' and 'sexual harassment', which are used in many law review articles addressing street remarks (e.g. Bowman, 1993; Davis, 1993; Heben, 1994; Nielsen, 2000; Tran, 2015). (See Vera-Gray (2016) for a discussion of different names for street remarks and the more general tension between legal and phenomenological approaches to them that different names reflect.)

I analyze popular interpretations of this set of street remarks as expressed in 1000 consecutive comments made by viewers of the YouTube video in late 2015. Although the video had been sponsored by an anti-street harassment organization and presented a plea for donations, most of the comments on the video argued that (most of) what the video documented was not harassment. Comments defending the street remarks as civil outnumbered comments condemning them by a ratio of over 2.5 to 1 . Seemingly paradoxically, both critics and defenders of the remarks use the very same compilation of 20 brief video-recorded encounters as evidence to support opposing positions.

I suggest two related reasons why the comments tend toward defense of the remarks as civil (even though the video was sponsored by an anti-harassment organization). First, popular perception and much scholarly work on street harassment tends to conceptualize street harassment in terms of the content of what is said, for example, as 'vulgar suggestions and outright threats' (Bowman, 1993). However, the literal content of the street remarks in this collection - for example, 'Have a nice evening' or 'How are you doing?' - is not explicitly vulgar or threatening. Comments that defend the street remarks in this recording as civil consistently highlight the literal meanings of words and conventional surface meanings of such acts as 'greeting' and 'complimenting':

1) how can u say people saying hello and have a good evening as harrasment (9 October 2015, 10:03:46 p.m.)

2) They were not harassmenst but compliment (30 October 2015, 8:21:23 p.m.)

Such comments reflect a referentialist view of meaning (Collins, 1996; Mertz, 2007), a linguistic ideology that sees meaning residing in conventional referential meanings of 
linguistic forms, irrespective of the interactional or social context in which these forms occur.

A second reason that so many comments defend the street remarks is that the video can be experienced as a criticism of men's position of power in society. As described by Jane (2014a, 2014b) and exemplified by attacks on Feminist Frequency website founder Anita Sarkeesian in 2012, gendered vitriol directed at women or organizations that champion gender equality is the rule rather than the exception in anonymous online discourse. Many dozens of the posted comments in the sample are angrily and explicitly misogynistic, for example, 'your a dumb bitch fuck you and your organization', disparaging Roberts in sexist terms and criticizing Hollaback, the non-profit movement that had commissioned the video. The term 'feminist' was used 64 times in the comments, nearly always in disparaging ways, for example 'Dam feminist'. Accepting that such street remarks are harmful to women could be very threatening to many men, who, like any group in power, tend to take their relative privilege for granted and see it as nothing other than the natural order of things. Many individual comments combine sexist or misogynistic comments with assertions that the street remarks are civil, suggesting a very close alignment between those two positions. Arguing that the comments are civil rather than harassment may thus be more an exercise, whether conscious or not, in rationalizing gender inequality than a function of disinterested, sincere interpretation of the recorded street encounters.

The 79 comments that characterize the street remarks in this video as harassment do not make arguments in the monolithic way ('They are just greeting and complimenting her') that defenders of them do. Women often experience street remarks as threatening invasions, and many feminist scholars emphasize their role in enacting and reproducing patriarchy (Di Leonardo, 1981; Kissling, 1991; Stanko, 1985, 1990; Tuerkheimer, 1997). The great majority of the comments critical of the remarks in this video, however, lack a commonsense vocabulary with which to articulate the mechanisms of their harm (cf. what Davis, 1993, describes as 'Harm that has no name'). The most common argument (occurring 39 times) among these 79 comments is that the relatively benign literal content of the remarks does not make them benign in intent or effect and that there is often a sexual intent behind them. The frequency of this type of comment may be partly a function of the dominant argument in the comments section that 'The men were just greeting her and sometimes complimenting her'. These critics argue that the street remarks cannot be taken literally, at face value, but rather must be understood as manifestations of other speaker intentions:

3) Reading these comments are crazy. They're not saying it cuz they're being nice. They're saying it cuz they wanna fuq (27 October $2015,10: 02: 50$ p.m.)

Their argument is that the meaning of the remarks must be understood not from a literal semantic or (surface) speech act perspective, but from a more social, pragmatic perspective of human interaction. These critics, however, do not describe how the claimed discrepancy between surface content and perceived intentions is particularly harmful or threatening.

Another 27 of the comments that criticize the street remarks argue that the commenters have had street remarks directed at them, that one can't understand street remarks 
unless one has been the target of them, or that if men were to switch places with women they might then understand their harm:

4) Its when they are disrespectful when its an issue. have you ever been treated like than on the street? even if its nice things being said it doesnt feel pleseant. (11 December 2015, 12:41: 12 a.m.)

Such comments suggest the pragmatic effects of street remarks in terms of the subjective experience of the targeted female but do not specify how specific forms or actions lead to these feelings. The last comment captures the discrepancy between literal meanings of words and their possible effect: 'even if its nice things being said it doesnt feel pleseant'. The literal meanings of the words may be 'nice', but at a social or pragmatic level they can be 'disrespectful' and feel unpleasant.

Silverstein (1981) has shown that the ability of native speakers to articulate formmeaning relationships is closely tied to particular semiotic properties of the communicative forms in question. According to Silverstein, our awareness and understandings of meaning are dominated by linguistic reference, even though reference is only one pragmatic channel of communication among many. While it is relatively easy to point out the literal, conventional meaning of 'Have a nice day', it is much more difficult to articulate how such a remark can be threatening or insulting. Such an argument involves articulating notions of context, social relationships and social conventions that typically remain unconscious and implicit in social interaction. The difficulties of identifying the precise mechanisms by which street remarks are threatening or insulting and transgress the interaction order (Goffman, 1983) may thus veil their harm and indirectly contribute to the perpetuation of male domination of women in public spaces.

In this article I first review data sources and methods and present transcripts of the 20 brief encounters documented in the YouTube video that generated the comments. I then describe patterns of competing interpretations of the encounters from a set of 1000 comments posted to the video, highlighting the logic and frequency of arguments used by both critics and defenders of the comments. I show that misogynistic comments are often closely juxtaposed with assertions that street remarks are civil. This serves as evidence that claims of street remarks-as-civil are not necessarily sincere interpretations by a disinterested party and might be better explained as exercises in defending patriarchy by rationalizing men's street remark behavior. Finally, I use language and logic from sociolinguistics and Goffman's interaction order to (a) illustrate specific ways in which greetings and terms of endearment, which are typical of street remarks, violate norms for civil interaction, thus undermining social trust, and (b) show how technical sociolinguistic language and logic relate to the folk notions expressed in critics' comments about the street remarks.

\section{Data and methods}

The use of electronically recorded street remarks as a data set in this article distinguishes it from the vast majority of scholarly work on men's street remarks to women, which has relied on self-reported instances of remarks based on memory (but see Bailey, 2016; 
Brouwers, 2015; Duneier and Molotch, 1999). This is significant because social scientists have repeatedly shown that memory is imperfect and selective. This might explain why scholarly analyses of street harassment that rely on self-report and interview data have tended to focus on explicitly vulgar and threatening remarks, which are more likely to be remembered than such mundane remarks as 'How are you this morning?'. However, vulgar and threatening content occurred in fewer than $10 \%$ of the encounters in a corpus of 134 electronically recorded encounters from seven different locations analyzed in Bailey (2016), and such remarks did not occur at all in '10 Hours of Walking in NYC as a Woman'. Use of electronically recorded collections can thus reframe our very notion of what constitutes a street remark, showing, for example, the extent to which street remarks are composed of words and acts that are civil in terms of literal or surface meanings.

Although this video provides an empirical record of street remarks to be interpreted and analyzed by YouTube commenters and the author and readers of this article, it does not represent a random or systematic sample of them. The video producer chose a particular target female, particular neighborhoods, and particular times of day to record, and the encounters in the posted, edited compilation video represent only a selected subset ( $20 \%$ by Bliss's count) of the street remark encounters that were recorded. Bliss noted that he edited out instances in which the male speaker was off-camera or the audio was of poor quality because of sirens or other background noise. An implicit bias in the selection process was the goal to attract viewers and affect them in order to raise awareness of street harassment. This might lead to overrepresentation of the most harassing (e.g. vulgar, insulting, or threatening) encounters, but there were only two encounters that commenters found particularly threatening, both cases in which the target female was not simply addressed but was also followed by males. While the desire to attract as much attention and audience as possible might lead to overrepresentation of surprising, vulgar, or threatening street remarks, the most frequent remarks in the edited compilations in both Bliss's video and a larger corpus of 134 encounters (Bailey, 2016) are relatively familiar and formulaic, combining a greeting and a term of endearment, for example 'What's up, beautiful?'

Viewer comments provide a range of popular interpretations of the 20 encounters documented in this short video. The comments are done relatively anonymously, through online user names, so one cannot correlate demographic variables, such as age or gender, with the comments. The anonymity has the research benefit of limiting the effect of social desirability (Crowne and Marlowe, 1960) on what is posted: commenters can feel relatively free to reveal ideas, for example racist and misogynistic ones, that they might not express in less anonymous contexts. A further benefit of such a source of interpretations is that they are user-initiated: people post of their own accord rather than in response to interview questions or focus group prompts from a researcher, so the researcher's biases and agendas do not shape the content of the comments.

To gather viewer comments on the YouTube video, I downloaded 1000 comments made between 19 October and 18 December 2015. (The tools I used, NCapture and NVivo, only download the most recent posts, and YouTube settings limit the downloadable number to 1000 at a time.) I read the comments (a) counting how many of them defended the street remarks in the video, arguing that they were not harassment, (b) counting how many of them argued that the remarks were, in fact, harassment, and 
(c) noting what characteristics of the 20 encounters were most likely to be referenced in comments. When critics or defenders of the remarks gave reasons for their claims I also noted these, grouping comments into categories based on the types of reasons they gave for their evaluation of the street remarks, for example 'They are not harassment because they are just greetings' or 'They are harassment because they have sexual intentions'. I also noted examples of comments that expressed explicit attitudes toward sex or gender. These were frequent and nearly always denigrated women, for example 'what a stupid cunt "I'm pretty and people tell me so!" She's not even that hot'. These are important because they create a context in which other comments, for example, those defending street remarks, must be interpreted.

\section{The 20 encounters in ' 10 Hours of Walking in NYC as a Woman'}

In this section I provide transcripts of the 20 encounters documented in the 1-minute 56-second YouTube video '10 Hours of Walking in NYC as a Woman', in the order in which they are presented in the video. For each of the encounters, I give a brief description of the visible context from the video (cf. Brouwers, 2015), followed by a number in parentheses that represents the time into the video at which the encounter appears. These brief descriptions and time notations are not meant to be analyses of context, but rather a means to help the reader and viewer of the video keep track of the different encounters, most of which are very brief and similar in form:

1. Four men, possibly construction workers on break, on folding chairs against a building facing the sidewalk. $(0: 13)$

S1 How you doing today?

S2 Smi:[le

S1 [I guess not goo[d

S3 [SMI::LE!

2. In the middle of a crosswalk, a male in shorts turns his head. (0:18)

S1 What's up beautiful have a good day

3. Several men sitting outside at a café $(0: 21)$

S1 Hey what's up gi:rl?

How you doing?

(S1) Somebody's acknowledging you for being beautiful

You should say thank you!

(S2/S3) For real?

4. A man with backward cap whom Roberts overtakes on sidewalk (0:29).

S1 $\quad<$ God bless you mami $>$

(1.2)

Damn! 
5. Man in front of restaurant, leaning on a cane and holding a can (0:32).

S1 Hey baby

6. Male speaker off screen $(0: 35)$.

S1 He:y beautifu:1!

7. Man sitting on a small post smoking a cigarette, as if on break (0:35).

S1 How are you this morning?

8. A man in passing, turning his head (0:39).

S1 > Have a nice evening $<$

9. Male speaker off screen, walking under scaffolding (0:40).

S1 Ni:ce!

10. Male speaker off screen, in front of video screen (0:42).

S1 Day:um

DAYumm!

11. Two men in front of building $(0: 45)$.

S1 Hi beautiful

(.3)

S2 God bless

(1.0)

S2? Sexy- American Eagle!

12. Man she overtakes on sidewalk (:50).

S1 Hello good morning

(1.2)

God bless you have a good day alright?

(Man matches her pace and walks beside her in video. Text in the video states that he does this for 5 minutes.)

13. Two men leaning against storefront $(0: 50)$.

S1 Da:mn!

S2 How you doing?

14. Sitting male street vendor (1:12).

S1 How you doing, goo:d?

(.3)

Sweetie?

15. A man standing still, possibly a vendor, dressed in purple (1:13).

S1 He:y look it there!

(0.8)

I saw a thousand dollars 
16. A man passing on sidewalk and turning his head (1:17).

S1 Damn, girl

17. A man walks alongside Roberts, turned toward her (1:19).

S1 (4)

You don't wanna talk?

(scene missing from video)

Because I'm ugly?

(1)

Huh?

(scene missing from video)

We can't be friends, nothing?

(1.2)

You don't speak?

(scene missing from video)

If I give you my number, would you talk to me?

(1)

Huh?

(1)

Too ugly for you?

18. Male not visible on camera $(1: 36)$.

S1 What's up, miss?

19. Male sitting on a guardrail smoking a cigarette.

S1 How you doing?

20. Two men standing in front of store window.

S1 Have a nice evening darling

\section{Viewer comments on the video}

Of the 1000 comments, over 200 of them defended the street remarks in the video as civil behavior, and 79 of the comments characterized the videotaped remarks as uncivil harassment. Only comments that expressed an explicit perspective on whether the street remarks and encounters were civil discourse or street harassment were counted. Overtly misogynistic comments will be addressed separately later in the section entitled 'Sincere interpretations or exercises in patriarchy?'.

The majority of the 1000 comments did not argue whether the street remarks were civil or harassing, instead addressing other topics or issues. Relatively frequent among such comments were calculations of the frequency of street remarks based on 10 hours of actual video recording, observations that the YouTube 'like' rating bar had been disabled, observations that a disproportionate number of the men in the videos were African American, evaluations of the attractiveness of Shoshanna Roberts and how she was dressed, assertions that women enjoy men's attention, and various arguments and personal attacks among commenters, often about gender. 
Comments that characterized the street remarks as civil or polite overwhelmingly drew attention to literal meanings of words and conventional meanings of such acts as 'greeting' and 'complimenting'. There were scores of comments such as the following:

5) Cut the bullshit ... this is not harassment ... they were complimenting her ... (13 November 2015, 11:25:01 a.m.)

6) Saying hello is not harassment (16 November 2015, 2:36:50 p.m.)

7) This is not harassment they are just compliments (16 November 2015, 9:06:37 p.m.)

8) That was not harassment. Those are nice people trying to engage with you (19 November 2015, 5:19:34 a.m.)

Many comments treated the civility of the remarks as self-evident and adopted an ironic tone to suggest that calling (many of) the remarks harassment was misguided:

9) Do the parts where someone politely greeted her count as harassment too? (21 November 2015, 11:12:39 p.m.)

10) Wow so terrible, saying hi to someone!?!?! WE NEED TO END GREETINGS NOW! (15 November 2015, 7:04:16 p.m.)

Many of these comments quoted specific words or utterances from the video as evidence that the woman was being civilly addressed or even complimented:

11) 'Hello and have a nice day' is not harassment in any way you try to put it. Dont be stupid. (23 November 2015, 5:25:39 p.m.)

Like academic discourse analysts who present segments from recorded and transcribed interaction as evidence for a claim, some commenters assembled selected utterances from across multiple encounters:

12) How are you doing today

Have a good day

How are you doing?

God bless you

How are you this morning?

Have a nice evening

Hello, good morning

hi beautiful

how is it harrassment? (15 December 2015, 9:58:03 p.m.)

This last comment includes eight direct quotes extracted from the 20 encounters and then asks rhetorically how these can count as harassment. It treats the civil meanings of the utterances as self-evident and as contrary to notions of harassment. 
A similar rhetorical device used in dozens of comments was to (a) give specific examples of (relatively innocuous) words or utterances from the video, and then (b) parody the voice of a feminist or person who would criticize the street remarks as evidence of patriarchy:

13) ‘Have a nice day’ [PATRIARCHY INTENSIFIES] (9 November 2015, 12:20:42 p.m.)

14) 'have a good day' OMFG HARASSMENT, RAPE, YOU CISGENDER PIGS (28 October 2015, 1:03:47 p.m.)

15) Shit! He said hi? He called her beautiful? He asked how she was? He asked how her weekend was? SHIT CALL 911 RAPE RAPE RAPE SEXUAL HARRASMENT FUCK MEN KILL THEM ALL THEY RAPE CHILDREN HELP. (2 November 2015, 10:18:58 p.m.)

The rhetorical power of this strategy comes from the juxtaposition of seemingly benign language with an imputed overreaction by those promoting gender equality.

Dozens of commenters not only defended the men's remarks, but found fault with the interactional behavior of the target of the street remarks, Shoshanna Roberts. They argued that not only was Roberts not being harassed, but that her lack of response to the remarks directed at her showed her to be the uncivil one, not the men directing remarks at her:

16) why doesnt she reply to the people waying for her to have a nice day or a nice evening? Thats not harassment its just men being kind. (6 November 2015, 9:10:26 p.m.)

17) Most of these were just have a nice day kind of things. Videos like these make social problems that don't even exist and honestly it's pretty rude not to say anything if someone says have a nice day. (3 November 2015, 7:30:13 p.m.)

These defenders of the street remarks draw attention to the normative pattern from many contexts in which it is rude when one does not respond to a first-pair part such as a greeting, question, or compliment (Bailey, 2016, 2017; Duneier and Molotch, 1999; Schegloff, 1978).

The two encounters in which men followed Roberts (12 and 17), in contrast to the others, were virtually always condemned as harassment or threatening. While the 18 other encounters were fleeting - typically as Roberts passed men who were standing still or walking in the opposite direction, in these two longer encounters men walked alongside Roberts for extended periods. In encounter 12, text on the screen says that the man walked next to her for 5 minutes. In encounter 17, a man walks alongside her for more than 17 seconds (there are three cuts in the edited video during this 17 -second section, so it might have been much longer), repeatedly addressing her even as she does not look at him or respond to him. Many commenters distinguished between this 'following' of Roberts in the video and the other encounters and street remarks made to her, arguing that many of the remarks were civil or polite, but that the physical following was not: 
18) So following a girl is creepy as HELL, and I'm a guy! But when someone says 'Have a nice day!' or 'Good evening!', take it as a compliment:). (28 October 2015, 10:15:15 p.m.)

19) ... We all know this video was hardly harassment besides the following. No insults were said. (11 November 2015, 8:58:20 p.m.)

While many comments argued that the video did not depict harassment, nearly all comments that mentioned the fact that Roberts was physically followed characterized the following as a form of harassment.

The 79 comments that explicitly criticize the street remarks in this video tend to focus on pragmatic and contextual dimensions of the street remarks, rather than on the literal meanings of words and conventional meanings of acts such as 'greeting'. Pragmatic meanings are generated from constellations of surface features in particular contexts and take into account participant identities and cultural conventions for interaction (Leech, 2016 [1983]; Levinson, 1983). Accordingly, the arguments for why these street remarks constituted harassment tend to be longer and more complex than those that relied only on literal meanings.

The most common types of argument for why these street remarks constituted harassment were, in descending order of frequency,

a. the street remarks don't reflect good intentions or the men were just interested in $\operatorname{sex}(n=39)$;

b. the person posting had been targeted by such remarks before and therefore knew from personal experience that they are harassment $(n=27)$;

c. the men making remarks were bothering the women and demanding their attention $(n=12)$;

d. a stranger commenting on a person makes the person feel like an object or prey $(n=9)$; and

e. the comments were a form of random shouting at the target, not a form of address or human engagement $(n=8)$.

One posted comment could include more than one of these, or other, arguments, so the total number of arguments is larger than the total number of 79 comments.

About 39 of the posted comments - possibly responding to the dominant argument in the comments section that 'They were just greeting her and complimenting her in the video' - argue that the relatively benign literal content of the remarks does not make them benign in intent or effect and that there is often a sexual intent behind them:

20) ... Regarding being told to accept a compliment. You are completely ignoring context. You are simply thinking in black and white like oh compliments are good things therefore they must always be good and it's rude to ignore them. Compliments are not always good. They are not good when they are used as bait to get a woman's attention ... (11 November 2015, 8:51:25 p.m.) 
This critic argues that what looks like a compliment may be functioning as something other than a compliment, and it cannot simply be evaluated based on a conventional meaning. The idea that a compliment is simply 'bait' to achieve some other end suggests insincerity. Others note that men are singling out Roberts (as a female of reproductive age) for greetings:

21) For those saying 'saying hello and have a nice day isn't bad': I call BS. Why? Because those same people ignore everyone else walking by. They are obviously hitting on her and that is NOT ok. Quit trying to make excuses for harassment. (8 November 2015, 3:32: 15 a.m.)

This commenter suggests that one must look at a larger context, not just the literal meaning of the utterance itself, in order to interpret it. Since 'hello' or 'have a nice day' is not addressed to other passersby in the video - they occur only to address a young woman - they have a meaning of 'hitting on her', that is, aggressive, inappropriate flirtation.

About 27 of the comments that criticize the street remarks state that the commenters have had street remarks directed at them, that one can't understand street remarks unless one has been the target of them, or that if men were to switch places with women they might then understand their harm:

22) ... I deal with it all the time as many other women do also. Stop belittling us and speaking to us condescendingly for speaking out against it and saying that it makes us uncomfortable. We're not trying to make it illegal as some here have suggested, we are just expressing our experience of it and asking for those that do it and didn't think to care if it makes us uncomfortable, to care ... (15 November 2015, 10:38:03 a.m.)

23) Reading just a few comments makes me sick, saying its her fault? ... And it pains me to say but all the people saying this are probably men. Put yourself in a women's shoes, we are minding our own business and then a stranger starts yelling at us, and it's SCARY and it is NOT OKAY IN ANYWAY AT ALL, and it's called HARASSMENT and it is considered a CRIME ... (14 November 2015, 9:51:05 p.m.)

While such comments make clear the commenters' sense of injury, they do not articulate the mechanisms by which street marks are harmful. They appeal to personal experience and hypothetical role switches between men and women.

Smaller numbers of comments specified more precise offenses of street remarks. In all, 12 of the 79 criticisms of the street remarks characterized the street remarks as a demand for attention and an intrusion:

24) ... Normally, you'd imagine it's ok to say hello to people - but if you see a woman walking briskly minding her own business, she probably doesn't need to hear from you There's a time and place to greet/be friendly to strangers, and a single woman alone on the streets of NYC is made uncomfortable by random people aggressively trying to start conversations with her every corner she turns ... (18 November 2015, 11:09:56 a.m.) 
Nine of the critics noted that street remarks can make a person feel like an object or prey:

25) its uncomfortable being under a microscope and being harassed and treated like an object when you're simply trying to walk in public. they weren't simply saying hi. they were calling her baby, screaming damn, staring at her ass and boobs, following her, some even coming close to grabbing her arm. (12 December 2015, 2:43:07 a.m.)

Eight of the comments noted that street remarks did not represent interpersonal engagement but someone shouting or talking 'at' a woman rather than 'to' her:

26) I'm just saying it ain't like they coming up and introducing themselves TO you like you're a human being, they just yelling something AT you aka catcalling. U wouldn't like it if a bunch of dudes started yelling randomn come ons at $u$, would $u$ ? ... (1 November 2015, 9:12:51 a.m.)

All of these arguments make the point that while the street remarks contain elements commonly understood as civil ('it's okay to say hello to people'), the specific context and ways of speaking in these encounters make them uncivil.

While it is relatively easy to point out the literal, conventional meaning of 'Have a nice day', it is much more difficult to articulate how such a remark can be threatening or insulting. Such an argument involves articulating notions of context, social relationships, and social conventions that typically remain unconscious and implicit in social interaction. The most common argument - that the men were insincere in their greetings and compliments or that they just wanted sex (39 times) - failed to specify the mechanism of harm of sexually motivated, insincere greetings or compliments. Similarly, a significant number (27) of the critical comments noted that they knew from experience that street remarks were harmful but were unable to identify how or why they were harmful. The difficulties in articulating the mechanisms through which street remarks are harmful weaken the rhetorical force of arguments that they do harm, thus undermining efforts to combat male domination of women in public spaces.

\section{Sincere interpretations or exercises in patriarchy?}

The interpretations of street remarks as civil or complimentary expressed in these 1000 comments do not occur in a neutral communicative context, but in contexts, at several levels, of gender inequality. At the broadest social level, women have less political and economic power than men, traditional ideals of femininity are linked to deference to men, many women are fearful of gender-based physical violence, and men's ways of talking and behaving are considered a norm against which women's talk and behavior are defined (Brownmiller, 2013 [1975]; Thorne and Henley, 1975; West and Zimmerman, 1987). In a more local, communicatively constituted context - the comments section tied to this YouTube video - there are many dozens of explicitly misogynistic comments, but virtually none that denigrate men in the same ways. 
This is not distinctive to this particular video or comments section. Explicit, unbridled misogyny is a common online reaction to posts or sites seen as representing feminist ideas (Jane, 2014a, 2014b), regardless of the specifics of the posts or site. At an even more local level of context, within individual comments, misogynistic comments regularly co-occur with commenters' assertions that street remarks are civil, as will be described later.

The 1000 comments analyzed here contain many angry, sexist comments directed at Shoshanna Roberts. At least a dozen comments make disparaging references to Roberts in terms of her appearance ('She's so fucking ugly', 'lol she ugly as fuck', 'she is fat and ugly', 'She's ugly as a shit!') (cf. Jane, 2014b). Many comments refer to Roberts as a 'bitch', a disparaging term for females that has connotations of a female who is not sufficiently subservient in her behavior and demeanor (Sutton, 1995). This term is used in comments about her appearance ('hideous fat bitch') and in comments that criticize her behavior, for example 'Dam bitch' and 'Stuck up bitch', for not displaying gratitude for the street remarks targeted at her. The term 'bitch' occurred 33 times in the comments, nearly always in disparaging ways about women.

Many of the defenders of street remarks also make disparaging remarks about feminists, thus treating the posted video as part of a feminist agenda. Many comments defending the remarks have an angry tone and treat Roberts as a guilty offender rather than victim, for example 'Kill yourself you sexist bitch'. The comments also included the term 'feminazi' eight times (e.g. 'FUCKING FEMINAZIS'), a term popularized by talk show host Rush Limbaugh that compares feminists to the murderous, totalitarian party of Nazi Germany.

Crucially, in addition to the overall context created by the many misogynistic comments, many individual comments juxtapose (a) angry sexist or misogynistic comments, (b) pejorative comments about feminism, and (c) interpretations of the street remarks as civil. Such juxtapositions suggest close links between seeing street remarks as civil and misogynistic attitudes:

27) What the actual FUCK!! What a bitch ass whore. Those kind people are calling you beautiful and you just ignore them?? What an asshole. FUCK feminist pieces of shit like you. FUCK you. (17 November 2015, 7:32:53 p.m.)

28) That bitch was greeted by nice people saying 'god bless you' or 'have a nice day' but she wouldn't say ‘thank you' Fucking feminist West (11 December 2015, 9:27:41 a.m.)

These comments include and juxtapose gendered, pejorative references to Roberts, curses of Roberts and feminists, and a claim that the street remarks were civil, complimentary comments. The misogynistic content and tenor of such comments about Roberts and other women make it difficult to interpret the posters' characterizations of the street remarks as sincere or disinterested interpretations. The evaluations of the street remarks as 'nice people saying "god bless you"' or 'kind people are calling you beautiful' are not credible, given the vitriol immediately surrounding them. Instead, the local context of misogynistic comments within the post - as well as the frequency of misogynistic posts among the 1000 posts sampled - suggests that many comments defending street remarks 
as civil in this collection may be better explained as exercises in defending a position of gender power rather than a function of a semiotic interpretation of meaning.

In this collection, misogynistic comments always correlated with defense, rather than criticism, of street remarks when they were juxtaposed within a comment. There were no comments that combined (a) misogynistic terms with (b) condemnation of the street remarks. In other words, comments such as the following contrived example did not occur: 'The men were rudely imposing on a stuck up feminist bitch who was minding her own business.'

Misogynistic comments both reflect and reproduce patriarchy. As argued by Doyle (2011), the striking sameness of misogynistic comments across online forums, regardless of the specific writer or (feminist) target of the vitriol, suggests that basic issues of gender and power are what are at play:

And when you look at what they're saying, how similar these slurs and insults and threats we get actually are, they always sound like they're speaking to the exact same woman. When men are using the same insults and sentiments to shut down women ... we know that it's not about us [the specific targets of the vitriol]; it's about gender.

Arguing that street remarks are civil or complimentary may simply be a rationalization for a practice that perpetuates male power over women. Focusing on the civil literal meanings of many comments may provide a cover for ongoing exercise of privilege, just as the civil forms of many street comments - greetings and compliments - can provide a cover for their uncivil intrusion and imposed engagement, an issue addressed explicitly in the following section.

\section{Civil words and uncivil acts}

In this section, I shift focus from online comments about the video to sociolinguistic analysis of the street remarks themselves. I use language and logic from Goffman's interaction order and sociolinguistics to explain how 'greetings' and 'compliments' - which street remark defenders cite as evidence of the civility of the remarks - can represent uncivil behavior. This type of analysis is fundamental to understanding street remarks for several reasons. First, greetings combined with a term of endearment, for example ' $\mathrm{Hi}$, beautiful', are by far the most frequent type in electronically recorded collections (e.g. Bailey, 2016; Hadleigh-West, 1998). Second, in many contexts greetings and terms of endearment or other compliments are popularly understood as civil. Finally, such ostensibly civil words are regularly experienced as harmful by women targeted by street remarks. While this analysis represents an etic, analytical one, I show it to not only explain empirical patterns in the remarks but also to correlate in meaningful ways with the most common criticisms of street remarks as expressed in the comments: that they are insincere, that they don't feel good, and that they represent intrusions.

Greetings (and related forms of acknowledgment) and terms of endearment occur in 18 of the 20 encounters in this collection and are the most commonly cited evidence of civility in comments by street remark defenders. Scholars typically treat greetings as a basis of human social interaction and civility. Searle and Vanderveken (1985), for example, describe 
greetings as 'a courteous indication of recognition, with the presupposition that the speaker has just encountered the hearer' (pp. 215-216). A total of 13 of the 20 encounters included greetings or greeting substitutes (Sacks, 1975), such as 'Hello good morning', 'How you doing today?', 'Hey', and 'Hi'. Three of the encounters (2, 8, and 20) included words of leave-taking, such as 'Have a nice day' and 'Have a nice evening', which mitigate the threat to social relations of ending engagement and parting. The street remarks in four of the encounters consisted solely of words of greeting or leave-taking $(7,8$, and 19) or words of leave-taking with the honorific term of address 'Miss' (18).

While such acts as greeting and leave-taking can be a basis of everyday civility, their use in these encounters is socially marked. The speakers do not know Roberts, and strangers on busy streets in New York City do not typically greet each other in passing, as is evident from the video in which only Roberts is greeted. Goffman (1963) describes an urban, American behavioral norm for relatively anonymous passing of individuals in public places as 'civil inattention':

What seems to be involved is that one gives to another enough visual notice to demonstrate that one appreciates that the other is present (and that one admits openly to having seen him), while at the next moment withdrawing one's attention from him so as to express that he does not constitute a target of special curiosity or design. (p. 84)

Rather than constituting civility, these greetings undermine it by violating the norm of civil inattention, treating Roberts as a 'target of special curiosity or design'. As described by Gardner (1980: 331-333), women, especially youthful ones, are treated as 'open persons' who can be approached and engaged by others at will. As open persons, they join those who are out of everyday roles. Gardner gives examples of people walking down a street in wedding clothing or hopping down the street on one foot, and groups, for example children, who can be addressed by others at will. Goffman (1963) explicitly links this open status to low status:

there are broad statuses in our society, such as that of old persons or the very young, that sometimes seem to be considered so meager in sacred value that it may be thought their members have nothing to lose through face engagement, and hence can be engaged at will. (pp. 125-126)

The selective greeting of young women by strangers not only violates the norm of civil inattention, it enacts a status differential, constituting the remarker as higher status and the target of the remarks as an open person of lower status.

Like greetings, 'terms of endearment' are civil in some contexts - connoting intimacy and caring - but here transgress the interaction order and represent the exercise of power over the target of the remark. Terms of endearment are a specialized term of address used to address a person - typically a lover, family member, or close friend - for whom one feels love or affection. In 9 of the 20 encounters, Roberts was addressed with terms of endearment: 'beautiful' (three times), 'girl' (twice), and 'baby', 'sweetie', 'darling', and 'mami' (Spanish for 'baby'). Five of the encounters (2, 5, 6, 14, and 20) consisted solely of words of greeting or leave-taking with an added term of endearment, for example 'What's up 
beautiful have a good day'. The combination of greeting/leave-taking with a term of endearment (and no further words) was thus the modal street remark in this collection of 20 encounters.

While terms of endearment are a valued way to mark intimacy and compliment an intimate, their use here - where the speaker does not know the addressee, much less have an intimate relationship with the addressee - is a highly marked violation of the norm of civil inattention. Language is performative, or constitutive (Austin, 1962), and these metaphorical terms of endearment attempt to define the speaker's relationship to the target female in a particular way, conjuring and imposing a fleeting fantasy of interactional engagement and of heterosexual intimacy between speaker and hearer. Because these forms are context-entailing (Silverstein, 1981) - creating a context or social reality through their utterance, rather than reflecting a pre-existing reality - their functioning and inappropriateness are particularly difficult to articulate.

When use of terms of endearment is non-reciprocal and when it is between nonintimates, it also represents an enactment of power (Wolfson and Manes, 1979). When a non-intimate is addressed with a term of endearment in a way that cannot be reciprocated - as when an adult addresses a child as 'Honey' - it suggests that the addressee is subordinate to the speaker. Addressing unacquainted women with a term of endearment not only conjures a fleeting, one-sided heterosexual intimacy, but also represents a claim and enactment of power over women.

The rules of Goffman's interaction order are implicit in the symbolic, ritual acts of everyday interaction. Through symbolic acts we display and confirm the 'sacredness' (Goffman, 1967: 46) or value that we allot to self and other and thereby cooperatively sustain a basis for social trust and civil interaction. Social and personal risk is inherent in human interaction, and when this risk is not mitigated through ongoing ritual acts - or worse yet, when the machinery of polite interaction, such as greetings, is co-opted for other ends - 'the individual teeters on social vertigo' (Duneier and Molotch, 1999: 1290).

Street remarks flout the normative conventions for interaction through which we manage risk and establish trust by imposing inappropriate intimacy on passing strangers. Women targeted by street remarks treat them as breaches of the interaction order by not responding to them despite the powerful normative pressure to respond to first-pair parts of greetings, questions, and compliments. It is at the level of the implicit interaction order, rather than 'vulgar suggestions and outright threats' (Bowman, 1993), that most of the street remarks in this collection do their harm.

Critics of street remarks in this collection do not use the technical terms of Goffman or sociolinguistics, but the forms of their arguments have clear correlates with more technical, conceptual explanations of how street remarks are injurious. The most frequent explanation $(n=39)$ for why commenters found street remarks uncivil was that the men did not have good intentions or had hidden sexual intentions. While insincerity and sexual intentions are part-and-parcel of many interactions, street remarks are particularly insidious. They masquerade as types of talk - civil greetings and forms of address - that in other contexts create a foundation for civil engagement, but in this case undermine the very trust that is the basis for all further human interaction.

The fact that these ground rules operate below the level of consciousness explains why so many critics of the street remarks $(n=27)$ are unable to articulate the mechanism of 
their harm, simply arguing that they had experienced street remarks and did not like them. This results in comments that note both the positive literal meanings of utterances and, simultaneously, the overall negative experience of the interaction ('even if its nice things being said it doesnt feel pleseant'). The exercise of power implied by street remarks is also suggested by the comments that argue that men would understand their harm if positions were reversed ('Put yourself in a women's shoes'), an argument commonly used when groups with less power are asked to explain how or why they feel marginalized.

Finally, the argument by 12 commenters that street remarks represent an unsolicited, unwelcome intrusion fits precisely with Goffman's notions of 'civil inattention' and the hierarchy enacted through being treated as 'open person', who can be addressed and engaged by others at will.

In this section I have illustrated ways in which the ostensibly civil words in this collection of street remarks can represent uncivil acts. These explanations link empirical patterns in the street remarks (e.g. frequent greetings and terms of endearment) with the enactment of power over women. These technical explanations have clear correlates in the non-technical language that critics of street remarks use in descriptions of their personal experience of such remarks and their arguments about the injury of such remarks.

\section{Conclusion}

Contrary to popular and much scholarly belief, street remarks are not necessarily characterized by explicitly vulgar and threatening words. Most of the things men say to a passing woman in the collection presented here (and in a larger electronically recorded collection; Bailey, 2016) are mundane or even complimentary in terms of literal meanings. Such literal meanings are readily available to discursive consciousness, and defenders of street remarks regularly refer to these civil or complimentary meanings in the comments they post in response to this video.

Women, however, regularly experience street remarks as harmful and reject them by ignoring them. It is not the literal content of the words, which can be complimentary, or the surface acts, such as greeting, that lead women to ignore them. Rather, it is their violations of the interaction order, the ground rules of face-to-face interaction that moderate social and personal risk. Men making street remarks use the trappings of civil interaction to impose, however transiently, a fantasy of engagement and intimacy on a passing woman, and when they do not achieve it, they sometimes reprimand the target of their remarks. In flouting implicit rules of civility - for example, 'Don't address strangers as if they were intimates' and 'Don't assert power over adult strangers on the street' - men making street remarks show themselves to be untrustworthy as interlocutors.

The harm of street remarks is not merely a symbolic harm in a ritual interaction order discrete from social life. The interaction order is part-and-parcel of life in a society where men are dominant and women are subject to gender-based violence. As described by Tuerkheimer (1997), 'being harassed on the street is a vivid reflection of male dominance and an inescapable reminder of the vulnerability of women to harm' (p. 13). The lack of a commonsense language for articulating these ways in which street remarks are injurious may veil their harm and indirectly contribute to the perpetuation of male domination of women in public spaces. 
The fact that the civility of the literal words contrasts with the incivility of the acts in this collection of street remarks can, in theory, afford contrasting interpretations of them. However, the frequency and vehemence of misogynistic comments posted to this video - often closely juxtaposed with defense of street remarks - would seem to swamp more subtle questions of semiotic levels of interpretation. In this context of often-explicit misogyny, the assertions that street remarks are civil or complimentary may be better explained as a rationalization for a practice that perpetuates male power over women than as a sincere interpretation of meaning. Such rationalizations function as a 'disciplinary rhetoric' designed to 'silence the women participating in public as feminist' (Cole, 2015: 356). Such a strategy, whether conscious or not, is not new or unique to interpretations of street remarks or to online platforms. Henley and Kramarae (1991: 42), for example, long ago argued that in many cases in which men and women give contrasting interpretations of communicative behavior, it is not a matter of interpretation but of power differentials and struggles: 'The construction of miscommunication between the sexes emerges as a powerful tool, maybe even a necessity, to maintain the structure of male supremacy.' If conflicting accounts of street remarks are framed as matters of interpretation, it diverts attention from the ways in which they exercise and reproduce male power over women and prevents their harm from being addressed.

\section{Declaration of conflicting interests}

The author(s) declared no potential conflicts of interest with respect to the research, authorship, and/or publication of this article.

\section{Funding}

The author(s) received no financial support for the research, authorship, and/or publication of this article.

\section{References}

Austin JL (1962) How to Do Things with Words: The William James Lectures Delivered at Harvard University in 1955 (ed. Urmson JO). Oxford: Clarendon Press.

Bailey B (2016) Street remarks to women in five countries and four languages: Impositions of engagement and intimacy. Sociolinguistic Studies 10(4): 589-609.

Bailey B (2017) Piropos as a cultural term for talk in the Spanish-speaking world. In: Carbaugh D (ed.) ICA Handbook of Communication in Cross-cultural Perspective. New York: Taylor \& Francis, pp. 195-207.

Bowman CG (1993) Street harassment and the informal ghettoization of women. Harvard Law Review 106(3): 517-580.

Brouwers C (2015) How you doing today? MA Thesis, Leiden University, Leiden.

Brownmiller S (2013 [1975]) Against Our Will: Men, Women and Rape. New York: Simon \& Schuster.

Cole K (2015) 'It's like she's eager to be verbally abused': Twitter, trolls, and (en)gendering disciplinary rhetoric. Feminist Media Studies 15(2): 356-358.

Collins J (1996) Socialization to text: Structure and contradiction in schooled literacy. In: Silverstein M and Urban G (eds) Natural Histories of Discourse. Chicago, IL: University of Chicago Press, pp. 203-228. 
Crowne DP and Marlowe D (1960) A new scale of social desirability independent of psychopathology. Journal of Consulting Psychology 24(4): 349-354.

Davis D (1993) Harm that has no name: Street harassment, embodiment, and African American women. UCLA Women's Law Journal 4(2): 135-178.

Di Leonardo M (1981) Political economy of street harassment. AEGIS: Magazine on Ending the Violence Against Women, Summer 51-57.

Doyle S (2011) But how do you know it's sexist? The \#MenCallMeThings round-up. Tiger Beatdown, 10 November. Available at: http://tigerbeatdown.com/2011/11/10/but-how-doyou-know-its-sexist-the-mencallmethings-round-up/ (accessed 3 April 2017).

Duneier M and Molotch H (1999) Talking city trouble: Interactional vandalism, social inequality, and the 'urban interaction problem'. American Journal of Sociology 104(5): 1263-1295.

Gardner CB (1980) Passing By: Street remarks, address rights, and the urban female. Sociological Inquiry 50(3-4): 328-356.

Gardner CB (1995) Passing By: Gender and Public Harassment. Berkeley, CA; Los Angeles, CA: University of California Press.

Goffman E (1963) Behavior in Public Places. New York: The Free Press.

Goffman E (1967) Interaction Ritual: Essays on Face-to-Face Interaction. Garden City, NY: Anchor Books.

Goffman E (1983) The interaction order: American Sociological Association, 1982 Presidential Address. American Sociological Review 48(1): 1-17.

Hadleigh-West M (1998) War Zone. New York, NY: Film Fatale, Inc.

Heben T (1994) Radical reshaping of the law: Interpreting and remedying street harassment. Southern California Review of Law and Women's Studies 4: 183-220.

Henley N and Kramarae C (1991) Gender, power, and miscommunication. In: Coupland N, Giles $\mathrm{H}$ and Wiemann JM (eds) Miscommunication and Problematic Talk. Newbury Park, CA: SAGE, pp. 18-43.

Jane EA (2014a) 'Back to the kitchen, cunt': Speaking the unspeakable about online misogyny. Continuum 28(4): 558-570.

Jane EA (2014b) 'Your a ugly, whorish, slut': Understanding e-bile. Feminist Media Studies 14(4): 531-546.

Kissling EA (1991) Street harassment: The language of sexual terrorism. Discourse \& Society 2(4): 451-460.

Leech GN (2016 [1983]) Principles of Pragmatics. London; New York: Longman.

Levinson S (1983) Pragmatics. Cambridge: Cambridge University Press.

Mertz E (2007) The Language of Law School: Learning to Think like a Lawyer. Oxford: Oxford University Press.

Nielsen LB (2000) Situating legal consciousness: Experiences and attitudes of ordinary citizens about law and street harassment. Law \& Society Review 34(4): 1055-1090.

Sacks H (1975) Everyone has to lie. In: Sanches M and Blount B (eds) Sociocultural Dimensions of Language Use. New York: Academic Press, pp. 57-80.

Schegloff EA (1978) On some questions and ambiguities in conversation. In: Dressler WU (ed.) Current Trends in Textlinguistics. Berlin: De Gruyter, pp. 81-102.

Searle JR and Vanderveken D (1985) Foundations of Illocutionary Logic. Cambridge: Cambridge University Press.

Silverstein M (1981) The limits of awareness. Sociolinguistic working paper no. 84. Austin, TX: Southwest Educational Development Laboratory.

Stanko E (1985) Intimate Intrusions: Women's Experience of Male Violence. London: Routledge \& Kegan Paul. 
Stanko E (1990) Everyday Violence: How Women and Men Experience Sexual and Physical Danger. New York: HarperCollins.

Sutton LA (1995) Bitches and skankly hobags: The place of women in contemporary slang. In: Hall K and Bucholtz M (eds) Gender Articulated: Language and the Socially Constructed Self. New York; London: Routledge, pp. 279-296.

Thorne B and Henley N (eds) (1975) Language and Sex: Difference and Dominance. Rowley, MA: Newbury House.

Tran M (2015) Combatting gender privilege and recognizing a woman's right to privacy in public spaces: Arguments to criminalize catcalling and creepshots. Hastings Women's Law Journal 26: 185-206.

Tuerkheimer D (1997) Street harassment as sexual subordination: The phenomenology of genderspecific harm. Wisconsin Women's Law Journal 12: 1-33.

Vera-Gray F (2016) Men's stranger intrusions: Rethinking street harassment. Women's Studies International Forum 58: 9-17.

West C and Zimmerman DH (1987) Doing gender. Gender \& Society 1(2): 125-151.

Wolfson N and Manes J (1979) Don’t dear me. Working paper no. 53. Austin, TX: Southwest Educational Development Laboratory.

\section{Author biography}

Benjamin Bailey received his $\mathrm{PhD}$ in linguistic anthropology from the University of CaliforniaLos Angeles and teaches in the Communication Department at the University of Massachusetts Amherst. His research focuses on language, culture, and social identities, particularly race and ethnicity. His publications include Language, Race, and Negotiation of Identities: A Study of Dominican Americans (2002, LFB Scholarly Publishing) as well as numerous articles and chapters on Dominican Americans, race, code switching, bilingualism, heteroglossia, intercultural communication, personal names, and street remarks.

\section{Appendix of transcription conventions}

S1 'S' with a number identifies a particular speaker.

(1.0) A number in parentheses indicates the number of seconds with no talk.

Smi:le A colon indicates the preceding sound was elongated.

Smi[le Brackets indicate the onset of overlapping speech [I guess

SMILE Capitals indicate emphasis through a combination of higher volume, higher pitch, and vowel elongation

(S1) ' $S$ ' with a number in parentheses indicates that it is not clear who is speaking

How you Underlined words are spoken with marked emphasis.

mami Italics indicate a word spoken in Spanish.

$<$ God bless you mami $>$

Words between outward pointing arrows are spoken in a slower, drawn out tempo.

$>$ Have a nice evening $<$

Words between inward pointing arrows are spoken at a rushed tempo. 